\title{
The Lost and Possessed Child in Henry James's The Turn of the Screw, William Friedkin \& William Peter Blatty's The Exorcist and Victor Kelleher's Del-Del
}

\author{
Adrian Schober
}

\begin{abstract}
A ssumptions about human nature are inseparably bound up with the representation of the child, whether in narratives addressed to an adult or child audience. The shifting visions of the child, whether as good or evil, innocent or corrupt can be traced back to the influence of the Calvinist/Puritan and Rousseauian/ Romantic traditions. When Calvinism was assimilated into Puritanism in the late sixteenth and seventeenth centuries, there was an emphasis on the inherent wickedness of the child, the child as damned, born in sin. This stems from the Christian doctrine of Original Sin: the belief that through the Fail from God's grace we are born into this world in a state of sinfulness, which is the underlying cause of all our actual sins. For the Puritans, discipline was a process of 'beating out' the moral blackness in the child, breaking its will, as it were, until it actively resisted its evil nature. To punish the child's body was to save its immortal soul. This view of the child was not challenged until the latter half of the eighteenth century. Far from being born evil, the child, according to Rousseau and the Romantics, was born innocent. For Rousseau, the child was truly innocent until corrupted by civilisation and 'culture'. In Emile, he argued that education should be geared to nurturing a child's unspoiled nature, its innate interests and capacities, instead of moulding (meaning: de-forming) that nature to suit society's ends.
\end{abstract}

David Grylls (1978) emphasises thepersistent competition and conflict between these two streams of thought about the child. Nina Auerbach stresses their persistent coexistence: 'Rousseau and Calvin stood side by side in the nursery' (1989, p.413). It is difficult, if not impossible, to think of one without thinking of the other: they not only compete with but, as is sometimes the case (in Dickens for example), inform each other. By the turn of the twentieth century writers began to exploit the possibilities of the child as a vessel, capable of being empty and full at the same time. It was this emptiness called the child (Kincaid 1992, p.71) that had allowed writers to 'fill' the child, to freely load it with significance: to be either good or evil, innocent or corrupt, ignorant or knowing, or both. The motif of the lost and possessed child became the perfect vehicle for discussing simultaneously these conflicting perceptions.
The motif of the lost child in its broadest sense as abandoned, rejected, stolen, forgotten, is very old. It has its roots in folklore and can be found in Shakespeare's late plays, Blake's Songs of Innocence and of Experience. and in various literary fairytales. The motif of the lost. possessed child is, however, comparatively recent. appearing in Henry James's The Turn of the Screw (1898) and later in The Exorcist. William Friedkin's film (1973) of William Peter Blatty's book(see note). The advantage of the possession motif for writers, as Neilson points out, is that it casts the child as both villain and victim:

Because the child does the evil deeds, he/she is a villain, but being under the dominance of another being, the child is actually innocent. This mix, the child as both villain and victim, has produced the most subtle and sophisticated of the evil child/ teenager stories, whether the rationale be psychiatric, religious, paranormal or simply demonic.

(Neilson 1990, pp. 192-3)

The relationship between childhood innocence and corruption and possession is problematised by the fact that sometimes the lost-possessed child is complicit in the possession. Herein lies the tension between Calvinist and Romantic ideologies, exemplified in The Turn of the Screw and The Exorcist. Victor Kelleher's Del-Del (1991) is a text for older children which likewise depends on specific tensions between opposing ideologies of childhood. Depending on our reading, the lost-possessed child in these narratives might be seen as a vessel of good or evil, innocence or corruption, ignorance or knowledge, or both.

In The Turn of the Screw, a young and inexperienced English governess becomes 'the vehicle for James's inquiry into the nature of 'seeing' and 'knowing', of illusion and reality, of ambiguity and certainty' (Shine 1969, p.133), in acting as first-person narrator. She is given full charge of the orphaned children, Miles and Flora. From the moment she is in the company of the children she is captivated by them, describing eight-yearold Flora as 'the most beautiful child I had ever seen' 
(1998, p. 124) and ten-year-old Miles, the 'mild child', as 'incredibly beautiful' (p.132). She repeatedly invests the brother and sister with angelic qualities and can barely find fault in the children, let alone reason to punish them. The reader is alerted to her possible unreliability as a narrator because of her exaggerated sense of selfimportance: she sees her presence at Bly as her 'calling', her 'golden opportunity', to save Miles and Flora. Only once does she question her own perception of reality, over the possibility of Miles's innocence, when she admits, ... and within a minute there had come to me out
of my very pity the appalling alarm of his being
perhaps innocent. It was for the instant
confounding and bottomless, for, if he were
innocent what then on earth was I?

(p.234)

But while her judgment might be questioned, it is difficult for readers to accept that the governess and Mrs Grose could both be swayed to the extent they are by the mere appearance of Miles and Flora, unless readers assume that supernatural forces are at work. It seems possible that this is what places the governess 'under the spell' (p.141) of her charges.

Central to the story is the Calvinist idea of the mind and body of children being peculiarly susceptible to corrupt influences and to invasions by spirits; they need to be protected. If the reader gives credence to the governess's account, then the ghosts of Peter Quint, the one-time valet at Bly, and Miss Jessel, her 'infamous' predecessor, want to possess the souls of Miles and Flora in order to corrupt them and ultimately destroy them. In their mortal incarnation, Quint and Miss Jessel contaminated the children with their evil. James doesn't spell out what that evil was, but the reader knows, for instance, that Quint was too 'free' with the boy (p.150).

On one level, James's treatment of the lost children Miles and Flora is more symbolic than realistic. He uses their innocence as a foil for the corruption of Quint and Miss Jessel, constructing the story in allegorical terms as the battle between good and evil, God and Satan. But James gives his story another 'turn' of the screw with the notion of youthful innocence masking terrifying evil, which might stand metaphorically for the latent evil in the world, whether primal, moral, or social - the devil in all of us. The governess gradually forms doubts in her mind about the children's seeming innocence. She starts to wonder if ' $[t]$ heir more than earthly beauty, their absoluteiy unnatural goodness' (p.181) hide secrets of an indescribably dark, diabolical nature. 'It's a game ...' she declares to Mrs Grose; 'it's a policy and a fraud!' (p.181).

Are Miles and Flora 'lost' at the end of the story? In the case of Flora, it seems that the infiltration of her soul is complete and Miss Jessel has 'won'. In the scene by the lake where Flora spurns the governess, the reader is told: 'The wretched child had spoken exactly as if she had got from some outside source each of her stabbing little words' (p.215). The governess dismisses her, saying: 'I've done my best, but I've lost you. Goodbye.' (p.215). A morally fallen Flora apparently walks away in a state of delirium, lost to evil, maybe damned. And Miles? Is he too lost? At one point, the governess tells Mrs Grose, 'I think he wants to give me an opening. I do believe that - poor little exquisite wretch! - he wants to speak' (p.219), though something appears to be stopping him. It would seem that the spirit of Quint has not taken him over completely and that there is hope for him yet. In the finale, the governess takes on the role of priest-exorcist to save Miles's soul from damnation, to draw from him a confession of his wickedness, but he is killed in the process, presumably by the 'violence of dispossession' (Beidler 1989, p. 198): his 'little heart, dispossessed, had stopped' (p.236). Whether the governess's exorcism is a victory or failure is open to debate. Miles's soul might be saved by the end but he pays a terrible price for redemption.

If the children are indeed possessed by evil spirits then this would exonerate them of their wickedness. After all, they could not be held responsible for their actions (the 'devil made them do it'); they are innocent. But it is possible that the children might be a willing party to Quint's and Miss Jessel's wickedness. If innocence in James's tale is to be construed as the child's lack of knowledge of evil, as Hoffmann (1957, p.84) suggests, the reader must decide how much the children know. If the reader accepts the governess's account, then the 
children apparently know more about the apparitions that haunt the estate of Bly than they reveal. The governess interprets the children's 'systematic silence' (p. 180) to mean that "while they pretend to be lost in their fairy-tale they're steeped in their vision of the dead restored to them'(p.181). This strongly suggests that the children are consorting with those spirits of their own volition.

The relationship between ignorance and knowledge and innocence and corruption is illustrated in a key exchange between the governess and Mrs Grose after the governess suspects that Flora is aware of her former governess's presence but is feigning ignorance. An unnerved Mrs Grose wonders if Flora might not mind and even enjoy the presence of Miss Jessel's spirit and that this might be proof of her 'blest innocence' (p.157) as Flora would not be perturbed by the spirit if she were blissfully unaware of its evil nature. She is only a child, after all. The governess makes the shaky reply: 'Oh, we must clutch at that - we must cling to it! If it isn't a proof of what you say, it's proof of - God knows what!' (pp.157-158). The governess's last words can be read to imply proof of corruption of Flora's soul: Flora is in league with the Devil and perfectly aware.

Miles may also have knowledge of evil. He changes in the governess's eyes from being an 'imperturbable little prodigy of delightful, loveable goodness' (p.163), 'knowing nothing in the world but love' (p.132) to a 'dark prodigy' whose world has been opened by the 'imagination of all evil' (p.205). Like Faust, the children may have sold their souls for knowledge and power (it is fitting, then, that the governess should call her charges 'cherubs', the second order of child-angels whose distinctive gift is knowledge) as consenting subjects of Quint and Miss Jessel. The way James plays off Calvinist with Romantic notions in the tale is deliberate and calculated to create indecision in readers, as Todorov's neighbouring genres of the uncanny (the governess is mad: the ghosts are figments of her over-active imagination) and the marvellous (the governess is sane: the ghosts are threateningly real) are invoked. To adopt one reading over the other is both to play the 'game'. and to miss the point: the tale is James's 'ultimate exercise in ambiguity' (Shine 1969, p.137)
The lost-possessed child made a spectacular impact in the 1970s with William Peter Blatty's book and William Friedkin's film The Exorcist (from an Oscar-winning script by Blatty), which was a literary, cinematic, cultural and social phenomenon. In this contemporary version of the lost-possessed child topos, pretty twelve-year-old Regan MacNeil is the seemingly happy and healthy American child of her famous movie actress mother, Chris. Regan is figured as the 'angel' in this Christian apocalyptic drama, the inspired vessel of beauty and purity who is the innocent and helpless victim of an alien invading intelligence.

Kinder and Houston argue that the film fails to enlist empathy from the audience for Regan's degeneration: 'our only reactions [to her] are curiosity and a delicious terror' (1987, p.47). I think their point is overstated. We care less for Regan as a child than for Regan as the symbolic representation of Child. Her possession represents a gross violation of the innocence of the Child and this is what is most disturbing and which earns our empathy for Regan's predicament. Nicholls writes that The Exorcist is a 'perfect modern example of an ancient heresy, the Manichean, in that it implies that the struggle between God and Satan is one of equals'(1984, p.137). The two priests that come to Regan's aid are unable to defeat the awesome power of the demon. As in James's tale, evil appears to have the upper hand.

Like The Turn of the Screw, The Exorcist appears to be arguing in Calvinist terms that the mind and body of the child are peculiarly susceptible to possession. There is, in particular, a sensational and unpleasant emphasis on the destruction of the body, and on the body as a temple of evil. In the course of the narrative Regan is shockingly transformed from angel to hellion, until she becomes a grotesque, monstrous version of her former self - the 'bad child' whose vile body urinates on the carpet and spews forth green bile, emasculates a psychiatrist, masturbates savagely with a crucifix (the ultimate violation of the body, as well as the crucifix), does $360^{\circ}$ head turns on her shoulders, and bellows obscenities and blasphemies of a highly sexual nature. She becomes more and more animal-like in the film, and more particularly in the novel: she howls; she barks; she mews; she neighs; she 
oinks; she grunts; she lows; she yelps; she hisses. The emphasis is on the destruction of the body for the demon wishes to possess her 'until she rots and lies stinking in the earth'.

The bad Regan is constructed as a changeling. In European folklore, the changeling (which means literally 'little changed person') was the deformed or imbecilic offspring of fairies or elves, dwarfs or gnomes, or of a witch or demon secretly exchanged by them for the parents' true child. The belief in changelings is derived from the idea that infants are particularly susceptible to demonic possession before the performance of certain purificatory rites, namely, baptism (Leach 1949, pp.208-209). Chris invokes this ancient belief when she tries desperately to convince Father Damien Karras - also a psy chiatrist - that Regan is 'not herself' anymore: 'You show me Regan's double - same face, same voice, everything - and I'd know it wasn't Regan. I'd know in my gut. And I'm telling you that thing up there is not my daughter.'

According to the changeling belief the original or true child can be brought back by torturing the changeling, or making it laugh (Leach 1949, p.208). In The Exorcist, physical punishment of the developing female body (seen here as monstrous) is used to 'regress' Regan's sexual development, and bring the 'old' Regan back. As Peter Biskind puts it, The Exorcist 'presents a male picture of female puberty. Emergent female sexuality is equated with demonic possession, and the men in the picture - almost all of them celibate priests - unite to abuse and torture Regan in their efforts to return her to presexual innocence' (1998, p.92). . There is a sexual tension between Regan and her exorcisers, Father Merrin and Father Karras, and this is particularly strong in the novel. 'Do you want to fuck her?' the demon asks Karras. 'Loose the straps and I will let you go at it.' (Blatty 1982, p.197) This is a gender reversal of the exorciser-exorcised relationship between the governess and her 'little gentleman' Miles.

Like Miles, Regan is also 'lost' inside her own body. In one of the film's key sequences, the words 'help me' appear in welts on Regan's body, indicating the 'real' Regan is a prisoner inside her own body. Like Miles, she is crying out to be saved. It also shows that Regan has some degree of awareness of what is happening to her. Her awareness is further intimated in the epilogue when Regan's gaze fixes on the Roman collar of Dyer and in an impulsive gesture, Regan reaches up to Dyer and plants a 'thank-you' kiss on his cheek - her way of thanking her saviours, Merrin and Karras, and, by implication, God. Regan remembers.

Friedkin-Blatty appear to go to great lengths to exonerate Regan from blame for her uncontroliable sociopathic behaviour. After all, it is the demon inside her forcing her to do terrible things. In the course of the narrative, explanations from physiology, psychology and physics are sought, with no success. For a while, we are in Todorov's ambiguous realm of the fantastic, split between the uncanny and the marvellous. But a rational explanation for Regan's symptoms is out of the question when her head revolves on it axis for the first time, much too far for physical capability. The viewer must make the imaginative leap into the marvellous and conclude that Regan is possessed. From this it would seem to follow that the demon inside Regan is to blame for her terrible deeds. She is innocent.

However, an alternative reading of the lost-possessed child in The Exorcist constructs Regan as not so innocent. This is suggested by her Shakespearean namesake, who was the thankless, monstrous daughter of King Lear, 'sharper than a serpent's tooth'. (Creed 1993, p.33; Kinder and Houston 1987, p.46). (In Blatty's novel, Chris almost calls Regan Goneril [1982, p.24], so the literary analogy is explicit). Barbara Creed identifies the incestuous-type relationship between mother and daughter as the main reason for Regan's possession and 'rebellion' in the film (1993, p.35). Regan's wish is to remain 'locked in a close, dyadic relationship with the mother' (Creed 1993, p.39) to the exclusion of others. In Burke Dennings, her mother's British movie director, she sees a potential father-figure - and a threat to the motherdaughter dyad. Earlier, Regan has revealed that she is jealous of Burke, whom she has heard her mother wants to marry. If only unconsciously, Regan (in a kind of variation on the Oedipal/Electral scenario) has a death wish for Burke. Later, in her evil incarnation, Regan's 
wish is fulfilled: Burke is thrown from her bedroom window, his head tumed completely around facing backwards to literally 'look the other way'(Creed 1993 , p.40). Now that Burke has been eliminated, mother and daughter can carry on together without anybody coming between them. Afterwards, when Regan the demon tries to force her mother to 'lick me!' by rubbing her face sensually in her bloody crotch, Regan says to her, in a wicked parody of Burke: 'Do you know what she did, your cunting daughter?' Thus it would appear that the demon has merely responded to a repressed desire on Regan's part. Regan's playing with an Ouija board also suggests she has opened up the gateway to evil herself.

Twenty years later the theme of possession made the crossover into children's literature in Victor Kelleher's Del-Del. Kelleher had already experimented with the theme of possession in Baily's Bones. Although owing something of a debt to The Exorcist, Del-Del writes (rewrites) the lost-possessed child in an urban Australian context. The possessed child here is seven year old Sam, a child prodigy. Narrated from the point of view of Sam's older sister Beth, the narrative is her determined attempt to piece together the events of the past to trace the causes of Sam's 'possession'. Beth's first person account contributes to the ambiguity the reader experiences. She frequently vacillates in her judgements about Sam, the extent of his guilt or innocence, sometimes (most disconcertingly) from one sentence to the next. Although she is insistent that her story is not a story, but 'truth', she is also quick to remind us that everything we are about to read is a reconstruction - and thus necessarily an interpretation - of events: 'Where did it all start then? When Laura died? Earlier? Later? Only Sam can answer that for sure' (p.l). Her self-effacing tone - she is by her own admission the 'quiet' one in the family, less than 'brainy', unlike her child prodigy of a brother (p.32) contrasts sharply with the govemess's frequent sense of importance in The Turn of the Screw. Beth tacitly acknowledges her unreliability as a narrator.

Like Regan and Miles and Flora, Sam can be seen as the innocent and defenceless victim of a malevolent invading intelligence, by what is first taken to be the devil and then an alien from outer space - or so it seems. In Part I: The
Beast, Beth describes Sam's possession by the Devil a.k.a the Beast, presenting good and evil, innocence and corruption, in a Christian context. Like James and Friedkin-Blatty, the innocence of the child (Sam) is cast as a foil for the corruption of the Beast, setting up the story as an antagonistic play between good and evil, God and Satan. Thus like Regan and Miles and Flora, Sam can be seen as an innocent symbolic child figure - at least initially.

On the anniversary of the death of his other sister, Sam starts behaving very strangely. In the cupboard of his bedroom, Beth is faced with a Sam quite unlike the Sam she has hitherto krown. Like Regan, he is like a changeling - the same, yet very different: 'His face, like the rest of the room, was somehow changed. Not physically. He was still the same skinny little kid as before, but with something different about him. And I mean really different, like looking at something you think and know and seeing a stranger. Someone who shouldn't be there' (1991, p.5). Now no longer Sam, he is somebody with a tell-tale lisp who answers to the name of 'Del-Del' (Del-Del: Devil?).

As happened with Regan, a psychological explanation is first sought. The diagnosis: that the real problem with Sam is a problem with the parents who, failing to deal with his giftedness and difference from other kids, have been projecting that failure onto him (p.27). In'locating the cause of Sam's disturbance somewhere in the home, it may be there is a grain of truth to the psychiatrist's diagnosis. Even Mum earlier concedes that: 'Sam's always been too much for us, Des. Be honest. We're none of us exactly stupid people, but Sam's in a different league altogether. We've never quite known how to deal with his kind of brilliance.'(p.22).

It pays to look briefly at the way Kelleher sets up the nuclear family in the novel. Mum is constructed as a strong and level-headed figure, as is her daughter Beth. Yet it is Mum's strength that is represented as specifically castrating (see analysis of the family dynamics in Scutter 1999, pp.215-222). Dad, feckless and wimpish relies on his wife to make decisions. On the few occasions he does act on his own initiative, as when he tries to take matters into his own hands by putting a lock on the cupboard where Sam has been consorting with Del-Del, he is in no 
way prepared for the sheer terror of Sam's agonised response'. Thus, just as there is an absence of father or father figures in The Turn of the Screw and The Exorcist, so the father in Del-Del often might as well be absent. Real strength emanates from the femaie.

As Sam's symptoms snowball - he too rolls his eyes back in his sockets and speaks English backwards - the rational explanation drawn from psychiatry is questioned. Readers are obliged to entertain a hypothesis based on the acceptance of the marvellous: that Sam is possessed. Sam becomes more and more like his doppelgänger Miles, as Beth recounts: '[It was] As if the person standing close to my bed wasn't a person any more, but a piece of the darkness that had somehow learned to think' (p.51), and like Regan he becomes increasingly feral, until he is a howling, growling; snarling, spitting, fighting, biting, clawing 'wild animal' (p.21).

The battle between good and evil seems to be brought to a head when Gran - the 'true believer' - takes Sam to the church to have the spirit banished from him. A stunned and horrified Sam cries in backwards English to an approaching priest: 'Yats kcab! Evas em morf eht rewop fo thgil! Evas em!' Gran is no fool; she seeks help from Hardcastle to perform the obligatory exorcism.

When it is believed that Hardcastle has succeeded in expelling the Beast from Sam there is a temporary reprieve. But rather than disappearing the Beast has merely changed its form. Part II: The Voyager describes Sam's possession by an alien survivor of a race on the brink of extinction, whose icy cold planet was catastrophically hit by a meteor. To escape extinction, the essences of the best minds among them Del-Del's - were sent voyaging into the far reaches of space, without destination. Desperate to find a place to rest from voyaging, Del-Del has found Sam's mind with a 'coolness at the centre, an icy core' (p.125), a place where he/she was able to survive. This paints a picture of Del-Del as no less than a parasite looking for a host, willing to do whatever it takes for self-preservation, even if it means putting Sam's life in danger.

As with Regan and Miles, Sam is a little boy who is lost and crying out to be found. According to Del-Del: "It is useless appealing to the child [Sam] ... He dwells where you will never reach him' (p. 161). Del-Del's account of Sam's possession creates the perception of Sam as victim of an alien body snatcher: 'Deftly I cut the links that bound him to his waking state. As he drifted away. I stepped into his place, took over his poor body which enclosed him'(p.128). It is difficult to not give a more unsettling picture of a little boy who has been stolen. There is a sense that Sam has been cast out - exiled - from his own body; he has lost touch with his own being

However, Part III: The Child assigns a disturbing rational explanation to the phenomenon of Sam. At no time has Sam been possessed, either by the Beast or an extraterrestrial. (Or in Todorov's scheme, readers have been moved from the uncanny to the marvellous, back to the uncanny.) Del-Del has been Sam's elaborate coping strategy to spare him the pain and grief of Laura's death: that is, Del-Del is Sam's 'cold, hard self (p.186), the self that doesn't care, who refuses to mourn, get hurt, or cry. Salvation for Sam consists of rescuing Beth from her fall down a precipice and proving to himself that he really does care. Free now to mourn for his dear sister, he can move - in the Kübler-Ross model of death and dying - to a stage of acceptance. Sam, 'the little boy who does not cry', can now learn to cry again. By the novel's close, Sam has become more of a realistic than a symbolic figure.

A strand running through The Turn of the Screw and The Exorcist, which is also powerfully present in Del-Del, is the Calvinist notion of the mind and body of the child being peculiarly susceptible to possession. As in The Exorcist, there are repeated references to the body, and the destruction of the body. When Beth notices Sam engaging in self-mutilation, she hears him [in his Beast incarnation] muttering: 'The uses of this flesh ... To feel pleasure, to feel pain, and to rot. Don't forget the rotting part.' (p.26). This echoes the demon's tine about possessing Regan 'until she rots and lies stinking in the earth.' However, the emphasis in $\mathrm{Del}-\mathrm{Del}$ is on the possession of the mind rather than the body, on the mind as a temple of evil. Del-Del the alien chose to infiltrate Sam in the first place: because of the 'cold space' in Sam's mind, where Del-Del is able to survive.

It is significant that Del-Del is drawn to the 'cold space'in 
Sam's mind, the seat of cool, unsympathetic intellect, and not his heart, the seat of emotion and compassion. Gran's seemingly throwaway remarks about Sam being a genius in his head, but in his heart a baby (p.10) speak volumes about Sam: that he is mentally advanced, but emotionally retarded; that his heart still has a long way to catch up with his mind. Del-Del makes known that: "

In the beginning ... there were two minds. The child's [Sam's] and another one, belonging to the girl Laura. While she was present the beacon signal was faint, unclear. But after her departure it gained in strength

(p.124).

This suggests that when Laura was alive, the beacon signal from Sam's cold mind (different from Laura's mind [p. 125]) was weak because Laura's warm heart was enough for both of them. When she dies, Sam's mind becomes even colder. Without Laura's (warm) heart to balance his (cold) mind, or a heart to call his own, the beacon signal from Sam's mind becomes perceptibly stronger to Del-Del. In these terms, Sam, the boy who does not cry, can be understood to need a heart, like the Tin Man in the Land of Oz. His 'Tin Man' status is unmistakable in the episode where Sam 'looks' for his own heart - and finds out that there's nothing (no-thing) there. This follows Sam and Mum's return from Brisbane after their stay with the other grandparents:

Chuckling to himself, he conducted a frantic search of the lounge room, peering under the coffee table, behind the couch, even up the chimney. Next, he began exploring his own body. pushing his hands up his clothes.

'No, he said decisively. 'No sign of a heart.' Finally he tapped his chest to show it was hollow. 'Nothing in here either, 'he declared, and broke into a peal of wild laughter which was so contagious that we all joined in.

(p.160)

Sam's 'heart condition' (like that of Regan), can be understood loosely in Freudian terms. His 'possession' is related to emotional repression, just as Regan's is related to sexual repression. It is through emotional release, or catharsis, that Sam's heart is healed; that which was lost has now found its way back home.

Like the two works examined earlier, Del-Del places the Romantic belief in childhood innocence in doubt. When possessed by the Beast or an extra-terrestrial, it would seem to follow that Sam, like Regan and Miles and Flora, is free from blame; his own will is, after all, under control by a strange and powerful force. He is innocent. However, the revelation that the 'possessions' were entirely Sam's invention, created by material deep in his subconscious mind, seems to refute the notion of the innocence of the child. In her epilogue, Beth is quick to redeem Sam, attempting to salvage that imnocence: 'There was certainly nothing evil about him. If you ask me, we all have a DelDel locked away in a cupboard somewhere; a hidden self we'd rather not acknowledge' (p.194). Her arguments about human nature sound suspiciously like Jung's shadow archetype, the so-called dark half of personality that has its roots in our ancestral past and contains, for example, our repressed desires and destructive tendencies. According to Jung, the person must fully acknowledge his/her shadow in order to be fully individuated (integrated and healthy). For this to occur the ego, the seat of conscious awareness, and the shadow must work together. When they do not, there is a kind of 'splinter personality'. If the shadow is totally suppressed, then the person risks revolt from his/her shadow. This will occur, for example, if there is some crises or weakness in the ego (Schultz 1990 , p. 101). In Sam's case, the ego crisis has been brought on by Laura's untimely death, resulting in a revolt from his shadow, 'personified' in Del-Del. The purpose of Beth's record is to help Sam acknowledge his shadow, to remind him of who he really is deep inside (pp.1 \& 195), so that Del-Del may never rear its ugly head again. Kelleher's point is that the real beast is the beast within; that evil is part of our biological makeup and not bound up with the Devil, Original Sin, or the paranomal.

Somehow the fact that Sam has never been possessed is a more disturbing state of affairs than if he had been possessed. Even if we allow for the fact that Sam's 'possession' was not a conscious, deliberate act of manipulation or calculation, one cannot help thinking that he has just delivered a tour-de-force performance: 
not only has he duped his family, but a psychiatrist, a holy man, and a university astronomer. Although only sevenyears old, Sam, by the formidable intelligence beneath his 'innocent mask'.(p.118), is well and truly a force to be reckoned with, more than a match for an adult's mind. We are reminded of threatening words to Beth: 'Temper, temper ... After all, consider what you're dealing with?' (p.25). Yes: what or who are we dealing with? Del-Del or, perhaps more terrifyingly, Sam? In the final analysis, Kelleher's stand on the extent of Sam's innocence or corruption is, like James's and Friedkin-Blatty's, highly ambiguous.

In closing, The Turn of the Screw. The Exorcist and Del$\mathrm{Del}$ allow for apparently contradictory readings of the lost and possessed child: the child as innocent (victim) and the child as corrupt (villain). Central to these constructions is the Calvinist assumption of the mind and body of the child being peculiarly susceptible to corrupt influences and to invasions by evil intelligences. Whether we adopt the victim or villain hypothesis, the possessed child in these narratives is figured as 'lost.' Lostness is constructed in various ways: in Christian terms, as a state of damnation where the child is morally fallen; as a state where the child is unable to find its way 'home' to the family; and/or as a state where the child has become dissociated from its own mind and body. In the effort to reconcile the tensions here between Calvinist and Romantic ideologies of childhood, it is necessary in our reading to incorporate the notion of a dialectic, where the ideas of the one influence, emphasise, inform and define our thinking of the other.

\section{NOTE}

Little Pearl of Hawthorne's dark moral tale set in Puritan Boston of the seventeenth century, The Scarlet Letter, is an early candidate for a lost-possessed child. It is the peculiar lost-damned look in her face, her eyes, that so unnerves her mother Hester Prynne and makes her wonder if 'an evil spirit possessed the child, and had just then peeped forth in mockery' (1995, p. 98). Hester's Puritan neighbours, moreover, decide that Pearl is the spawn of a devil.

\section{REFERENCES}

Auerbach, Nina (1989) 'Alice and wonderland: a curious child', in Harold Bloom (ed.)Victorian Fiction. New York, Chelsea House, pp.403-415.

Beidler, Peter G (1989) Ghosts, Demons, and Henry James: The Turn of the Screw and the Turn of the Century. Columbia, University of Missouri Press.

Biskind, Peter. (May 1998) 'Sympathy for the devil'. Premiere, 11, 9, 84-93, 102.

Blatty, William Peter(1982) The Exorcist. London, Corgi Books.

Combs, Richard. (Spring 1974) 'The Exorcist', Sight and Sound, 43, 2, 120.

Creed, Barbara (1993) The Monstrous Feminine: Film, Feminism, Psychoanalysis. London and New York. Routledge.

Grylls, David (1978) Guardians and Angels: Parents and Children in Nineteenth -Century Literature. London \& Boston, Faber and Faber.

Hawthorne, Nathaniel (1995) The Scarlet Letter. London, Bloomsbury Publishing .

Hoffmann, C.G (1957) The Short Novels of Henry James. New York, Bookman Associates.

James, Henry (1998) The Turn of the Screw and Other Stories. Oxford and New York, Oxford University Press.

Kelleher, Victor (1991) Del-Del. Milsons Point, Random House.

Kermode, Mark (1998) The Exorcist. London, British Film Institute (2nd edition).

Kincaid, James R(1992) Child-Loving: The Erotic Child and Victorian Culture. New York \& London, Routledge.

Kinder, Marsha, and Houston, Beverle (1987) 'Seeing is believing: The Exorcist and Don't Look Now', in G. A. Waller (ed.) Essays on the Modern American Horror Film. Urbana \& Chicago, University of Illinios Press, pp. 44-61. 
Leach, Maria (ed) (1949) Funk and Wagnalls Standard Dictionary of Folklore Mythology and Legend. New York, Funk \& Wagnalls (Vol. 1).

Mulvey, Laura (1989) 'Visual pleasure and narrative cinema', in Visual and Other Pleasures. Houndmills, Macmillan.

Neilson, Keith (1990) 'Contemporary horror fiction $1950-$ $88^{\prime}$, in Neil Barron (ed.) Horror Literature: A Reader's Guide. New York \& London, Garland Publishing.

Nicholls, Peter (1984) The World of Fantastic Films: an Illustrated Survey. New York, Dodd, Mead.

Rousseau, Jean Jacques (1960) The Emile of Jean Jacques Rousseau, trans. and ed. William Boyd. New York. Teachers College Press, Columbia University.

Schultz, Duane (1990) Theories of Personality. Pacific Grove, California, Brooks/Cole Publishing (4th edition).

Scutter, Heather (1999) Displaced Fictions: Contemporary Australian Books for Teenagers and Young Adults. Cariton South, Melbourne University Press.

Shine, Muriel G (1969) The Fictional Children of Henry James. Chapel Hill, University of North Carolina Press.

Todorov, Tzvetan (1975) The Fantastic: A Structural Approach to a Literary Genre, trans. Richard Howard. Ithaca, New York, Cornell University Press.

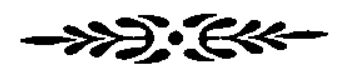

\section{Biographical Note}

Adrian Schober is currently doing his PhD at Monash University. His thesis is on lost and possessed children in film and literature.

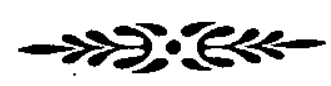

